\title{
EFEK PEMBATASAN PAKAN DAN SUMBER SERAT KASAR BERBEDA TERHADAP PERFORMA AYAM PEDAGING
}

\author{
Seruni Binowo, Bernat Tulung, Jola J.M.R. Londok*, Mursye N. Regar \\ Fakultas Peternakan Universitas Sam Ratulangi, Manado, 95115
}

\begin{abstract}
ABSTRAK
Penelitian ini bertujuan untuk mengetahui performa ayam pedaging strain Lohman yang diberi pembatasan pakan sebesar 20 persen dan 10 persen level serat kasar dari sumber serat yang berbeda yaitu kulit kopi, dedak padi dan ampas kelapa. Penelitian ini telah dilaksanakan di kandang unggas Fakultas Peternakan UNSRAT Manado, selama 6 minggu menggunakan 48 ekor ayam pedaging unsex strain Lohman umur 21 hari.Metode penelitian yang digunakan adalah Rancangan Acak Lengkap (RAL) pola faktorial $(2 \times 4)$ dan masing-masing kombinasi perlakuandiulang 3 kali. Sebagai faktor A yaitu pembatasan pakan dengan taraf faktor A0 (tanpa pembatasan) dan A1 (pembatasan pakan sebesar 20\%). Faktor B yaitu sumber serat dengan taraf faktor B0(pakan komersial), B1(pakan komersial dengan kulit kopi), B2(pakan komersial dengan dedak padi), dan B3(pakan komersial dengan ampas kelapa).Sehingga diperoleh 8 kombinasi perlakuan: A0B0, A0B1, A0B2, A0B3, A1B0, A1B1, A1B2 dan A1B3. Pembatasan $20 \%$ dan pemberian serat pakan dilakukan pada hari ke-21 sampai hari ke-28, setelah itu pakan diberikan ad libitum sampai berumur 42 hari. Variabel yang diukur adalah, konsumsi pakan, pertambahan bobot badan dan konversi pakan. Hasil penelitian menunjukan bahwa pembatasan pakan dan sumber serat
\end{abstract}

*Korespondensi (corresponding author): jolalondok_unsrat@yahoo.com berbeda memberikan pengaruh yang nyata $(\mathrm{P}<0,05)$ terhadap konsumsi pakan, pertambahan bobot badan dan konversi pakan. Hasil penelitian ini dapat disimpulkan bahwa, pembatasan pakan sebesar 20 persenselama 8 hari dengan sumber serat kasar ampas kelapa dalam pakan memberikan hasil terbaik dibandingkan dengan kulit kopi dan dedak padi terhadap performa ayam pedaging strain Lohman.

Kata kunci: Ayam pedaging, pembatasan pakan, serat kasar.

\section{ABSTRACT}

EFFECT OF FEED RESTRICTION AND DIFFERENT CRUDE FIBER SOURCES ON THE BORILER PERFORMANCE. The research aim was to determine the performance of Lohman strain broiler were given by food restriction of 20 percent and 10 percent levels of crude fiber from different fiber sources originated from coffee peel, rice bran and coconut pulp. This research was carried out in a poultry house at the Faculty of Animal Husbandry, UNSRAT Manado, during 6 weeks using 48 unsex Lohman strain broilers at 21 days old. The research method was using a Completely Randomized Design (CRD) based on factorial pattern $(2 \times 4)$. Each treatment combination was repeated 3 times. Factor A was a feed restriction consisting of feed without restriction (A0) and restriction of $20 \%$ feed for 8 days (A1). Factor $\mathrm{B}$ was a source of fiber consisting of control (B0); 
coffee peel (B1); rice bran (B2) and coconut pulp (B3). In this study, the were 8 treatment combinations of $\mathrm{A} 0 \mathrm{~B} 0, \mathrm{~A} 0 \mathrm{~B} 1$, $\mathrm{A} 0 \mathrm{~B} 2, \mathrm{~A} 0 \mathrm{~B} 3, \mathrm{~A} 1 \mathrm{~B} 0, \mathrm{~A} 1 \mathrm{~B} 1, \mathrm{~A} 1 \mathrm{~B} 2$ and A1B3. Application of feed restriction and source of fiber were applied during days of 21 th to day of $28^{\text {th }}$. The birds were fed commercial feed until 42 days of age. The variables measured were feed consumption, body weight gain and feed conversion. The results showed that the restriction of feed and different fiber sources had a significant effect ( $\mathrm{P}<0.05$ ) on feed consumption, body weight gain and feed conversion. The results of this study can be concluded that the restriction of feed by 20 percent for 8 days with a source of crude fiber originated from coconut pulp in feed gave the best response compared with crude fiber originated from coffee peel and rice bran on the performance of the Lohman strain of broiler.

Keywords: Broiler, feed restriction, crude fiber

\section{PENDAHULUAN}

Sektor perunggasan, terutama ayam pedaging komersial masih menjadi prioritas utama untuk pemenuhan kebutuhan akan konsumsi daging sebagai sumber protein hewani masyarakat. Ayam pedaging strain Lohman sama dengan ayam pedaging yang lain pada umumnya, yaitu relatif lebih mudah pemeliharaannya, memiliki cita rasa yang tinggi sehingga disukai mulai dari anak-anak sampai orang dewasa, selain itu nilai hayatinya tinggi, harganyapun relatif lebih murah dan bisa dijangkau oleh hampir semua strata sosial masyarakat.
Pemeliharaannya sangat cepat yakni lima minggu sudah mencapai berat jual ideal, sehingga sangat efektif dalam menghasilkan daging.

Pembatasan pakan (restricted feeding) merupakan salah satu strategi yang digunakan sebagai upaya untuk mengurangi dampak konsumsi pakan berlebihan yang diberikan ad libitum (Hasan et al., 2013). Selain itu dapat menurunkan konversi pakan. Pengaruh pembatasan pakan pada ayam pedaging pada dasarnya merupakan program untuk memberikan pakan sesuai dengan kebutuhan hidup pokoknya pada umur dan periode tertentu. Beberapa penelitian pembatasan pakan secara kuantitatif maupun kualitatif telah dilaporkan. Londok et al. (2012) melaporkan bahwa pembatasan pakan sampai $20 \%$ memberikan konversi pakan terbaik. Tulung et al. (2015) melakukan rangkaian penelitian dengan level serat kasar (sampai 10\%) serta lama pemberian (sampai 16 hari), hasil penelitian menunjukan tidak adanya interaksi antara kedua faktor tersebut terhadap performa pedaging, dilihat dari konsumsi, pertambahan berat badan, serta efisiensi penggunaan pakan, toleransi ayam pedaging terhadap lamanya pemberian pakan hanya sampai 8 hari dengan kadar serat kasar sampai 10\% dalam pakan. Serat kasar memiliki banyak manfaat bagi ternak yaitu membantu gerak 
peristaltik usus, mempercepat laju digesta dan memacu perkembangan organ pencernaan. Limbah hasil pertanian dan perkebunan cukup tersedia di Indonesia, namun potensinya belum dimanfaatkan secara optimal sebagai pakan ternak. Salah satu upaya yang dapat dilakukan adalah pemanfaatan limbah pertanian dan perkebunan seperti kulit kopi, dedak padi dan ampas kelapa sebagai pakan sumber serat kasar untuk pakan ternak unggas.

Penelitian dilakukan dengan tujuan untuk mengetahui performa ayam pedaging strain Lohman yang diberi pembatasan pakan sebesar 20 persen dan 10 persen level serat kasar dari sumber serat yang berbeda yaitu kulit kopi, dedak padi dan ampas kelapa.

\section{MATERI DAN METODE PENELITIAN}

Penelitian ini telah dilaksanakan di kandang percobaan ternak unggas Fakultas Peternakan Universitas Sam Ratulangi. Penelitian dimulai tanggal 11 Mei sampai dengan 22 Juni 2018. Ternak yang digunakan adalah ayam pedaging Strain Lohman umur sehari dari PT. Japfa Comfeed Indonesia. Ternak dipelihara sebanyak 100 ekor, sampai umur 20 hari, setelah berumur 21 hari diambil sebanyak
48 ekor dengan rataan bobot badan yang hampir sama yaitu sebesar 929,33 $\pm 34,06$ gram untuk diberi perlakuan. Kandang yang digunakan dalam penelitian ini yaitu kandang sistem batteray dengan ukuran 30 x 40 x $40 \mathrm{~cm}^{3}$ per unit. Setiap unit kandang ditempatkan 2 ekor ternak ayam dilengkapi dengan tempat pakan dan minum. Peralatan lainnya yang digunakan selama penelitian yaitu: lampu penerang, thermometer, kipas angin, wadah pencampur pakan, timbangan berkapasitas 2000 gram, kantong plastik penampung pakan perlakuan, alat tulis menulis dan alat kebersihan.

Penelitian ini menggunakan Rancangan Acak Lengkap Pola Faktorial 2x4 dengan 3 ulangan. Sebagai faktor A yaitu pembatasan pakan dengan taraf faktor A0 (tanpa pembatasan) dan A1 (pembatasan pakan sebesar 20\%). Faktor B yaitu sumber serat dengan taraf faktor B0 (pakan komersial), B1 (pakan komersial dengan kulit kopi), B2 (pakan komersial dengan dedak padi), dan B3 (pakan komersial dengan ampas kelapa). Terdapat 8 kombinasi perlakuan yaitu: 1). A0B0= kontrol, 2). A0B1= tanpa pembatasan dan pakan komersial dengan kulit kopi, 3). $\mathrm{A} 0 \mathrm{~B} 2=$ tanpa pembatasan dan pakan komersial dengan dedak padi, 4). A0B3= tanpa pembatasan dan pakan komersial dengan ampas kelapa, 5). 
Tabel 1. Komposisi Zat-Zat Makanan dan Energi Metabolis Bahan Pakan Perlakuan

\begin{tabular}{lccccccc}
\hline \multirow{2}{*}{ Bahan Pakan } & $\begin{array}{c}\text { Bahan } \\
\text { Kasar }\end{array}$ & $\begin{array}{c}\text { Protein } \\
\text { Kasar }\end{array}$ & $\begin{array}{c}\text { Lemak } \\
\text { Kasar }\end{array}$ & $\begin{array}{c}\text { Serat } \\
\text { Kasar }\end{array}$ & Kalsium & Pospor & $\begin{array}{c}\text { Energi } \\
\text { Metabolis }\end{array}$ \\
\cline { 2 - 8 } & $(\%)$ & $(\%)$ & $(\%)$ & $(\%)$ & $(\%)$ & $(\%)$ & $\left(\mathrm{kkal} \mathrm{kg}^{-1}\right)$ \\
\hline BR 21-E* & 88 & 22,00 & 6,00 & 5,00 & 1,05 & 0,85 & 3135 \\
Kulit Kopi** & 89 & 16,72 & 7,06 & 20,02 & 0,23 & 0,02 & 3063 \\
Dedak Padi*** & 86 & 7,91 & 5,91 & 23,37 & 0,22 & 0,95 & 2789 \\
Ampas Kelapa*** & 89 & 11,35 & 23,36 & 14,97 & 0,11 & 0,47 & 3280 \\
T. Ikan**** & 92 & 56,91 & 9,34 & 0,09 & 7,04 & 3,67 & 3852 \\
\hline
\end{tabular}

Keterangan: BR 21-E: pakan komersial. *Londok et al. (2018), **Tulung et al. (2015), ****ondok (2018)

Tabel 2. Susunan Pakan Perlakuan serta Komposisi Zat-Zat Makanan dan Energi Metabolis.

\begin{tabular}{|c|c|c|c|c|}
\hline \multirow{2}{*}{ Bahan pakan } & \multicolumn{4}{|c|}{ Sumber Serat (B) } \\
\hline & $\mathrm{B} 0$ & B1 & $\mathrm{B} 2$ & B3 \\
\hline BR 21-E & 100 & 65 & 62 & 41 \\
\hline Kulit Kopi & 0 & 35 & 0 & 0 \\
\hline Dedak Padi & 0 & 0 & 31 & 0 \\
\hline Ampas Kelapa & 0 & 0 & 0 & 50 \\
\hline Tepung ikan & 0 & 0 & 7 & 9 \\
\hline Total & 100 & 100 & 100 & 100 \\
\hline \multicolumn{5}{|c|}{ Komposisi Zat Makanan dan Energi } \\
\hline Bahan Kering (\%) & 88,00 & 88,24 & 87,54 & 88,72 \\
\hline Protein $(\%)$ & 22,00 & 20,15 & 20,08 & 19,82 \\
\hline Lemak (\%) & 6,00 & 6,37 & 6,21 & 14,98 \\
\hline Serat kasar $(\%)$ & 5,00 & 10,26 & 10,41 & 9,62 \\
\hline Kalsium (\%) & 1,05 & 0,76 & 1,21 & 1,12 \\
\hline Pospor (\%) & 0,85 & 0,56 & 1,08 & 0,91 \\
\hline $\begin{array}{l}\text { Energi Metabolis (kkal } \\
\mathrm{kg}^{-1} \text { ) }\end{array}$ & 3135 & 3110 & 3078 & 3272 \\
\hline
\end{tabular}

Keterangan: Dihitung Berdasarkan Tabel 1. 
$\mathrm{A} 1 \mathrm{~B} 0=$ pembatasan $20 \%$ dan pakan komersial, 6). A1B1= pembatasan $20 \%$ dan pakan komersial dengan kulit kopi, 7). $\mathrm{A} 1 \mathrm{~B} 2=$ pembatasan $20 \%$ dan pakan komersial dengan dedak padi, 8). A1B3= pembatasan $20 \%$ dan pakan komersial dengan ampas kelapa. Pakan yang digunakan pada penelitian ini adalah pakan komersial BR 21-E, tepung ikan, dan bahan pakan sumber serat kasar yaitu kulit kopi, dedak padi, dan ampas kelapa. Komposisi serta kandungan zat-zat makanan dan energi metabolis bahan pakan perlakuan dapat dilihat pada Tabel 1. Susunan pakan perlakuan serta komposisi zat-zat makanan dan energi metabolis tercantum pada Tabel 2.

1. Persiapan

Kandang dan lingkungannya dibersihkan kemudian didisinfektan menggunakan formalin. Menyiapkan kandang brooder yang dilengkapi dengan 2 buah lampu pijar masing-masing 100 watt sebagai sumber panas. Kandang perlakuan disiapkan sebanyak 24 unit dan diatur dengan rapih. Tempat makan dan air minum diletakkan secara teratur di setiap kandang.

\section{Pemeliharaan}

Pada saat ayam tiba di kandang penelitian, ayam ditimbang untuk mendapatkan data bobot badan awal, lalu diberi nomor kaki, kemudian diletakkan di dalam kandang brooder dan diberi air gula. Pemeliharaan dikandang brooder selama 7 hari dan diberi pakan komersial. Pakan perlakuan diolah dalam bentuk tepung (mash). Pakan perlakuan terdiri dari BR 21E, tepung ikan, kulit kopi, dedak padi dan ampas kelapa. Pakan perlakuan ditimbang sesuai standar kebutuhan yang diberikan tiap hari. Pada umur 7 hari, ayam dipindahkan ke kandang liter dan dipelihara sampai umur 21 hari. Pada umur 21 hari, ayam diambil secara acak, ditimbang untuk mendapatkan bobot badan yang seragam, lalu dipindahkan ke kandang baterai. Tiap unit kandang ditempatkan 2 ekor ayam, kemudian diberi perlakuan yaitu pakan sumber serat kasar dan pembatasan pakan 20 persen selama 8 hari, sesuai perlakuan yang ditetapkan. Setelah perlakuan, ayam kembali diberi pakan komersial ad libitum sampai umur 42 hari.

\section{Pengambilan data}

Data konsumsi pakan diperoleh dengan penimbangan pakan yang diberikan dan pakan sisa. Data pertambahan bobot badan diperoleh dengan menimbang bobot badan ayam setiap minggu.

Variabel penelitian yang diukur:

1. Konsumsi pakan (gram) diperoleh dari selisih antara jumlah pakan yang diberikan dengan sisanya setiap hari.

2. Pertambahan bobot badan (gram) diperoleh dari selisih penimbangan 
bobot badan akhir dengan bobot badan awal.

3. Konversi pakan yaitu perbandingan antara konsumsi pakan rata-rata ekor $^{-1}$ hari $^{-1}$ dengan pertambahan bobot badan rata-rata ekor $^{-1}$ hari $^{-1}$ selama periode penelitian.

\section{HASIL DAN PEMBAHASAN}

Data hasil penelitian untuk rataan konsumsi pakan, pertambahan bobot badan dan konversi pakan ayam pedaging strain Lohman selama penelitian dapat dilihat pada Tabel 3.

\section{Pengaruh Perlakuan terhadap Konsumsi Pakan}

Rataan konsumsi pakan selama penelitian (Tabel 3) menunjukkan bahwa nilai rataan konsumsi pakan bervariasi

Tabel 3. Rataan Konsumsi Pakan, Pertambahan Bobot Badan dan Konversi Pakan Ayam Pedaging Strain Lohman Selama Penelitian.

\begin{tabular}{|c|c|c|c|c|c|c|}
\hline \multirow{2}{*}{ Variabel } & \multirow{2}{*}{ Pembatasan Pakan (A) } & \multicolumn{4}{|c|}{ Sumber Serat (B) } & \multirow{2}{*}{ Rataan } \\
\hline & & B0 & B1 & B2 & B3 & \\
\hline \multirow{6}{*}{$\begin{array}{c}\text { Konsumsi } \\
\text { Pakan (gram } \\
\text { ekor }^{-1} \text { Hari }^{-1} \text { ) }\end{array}$} & \multirow{2}{*}{ A0 } & 156,96 & 151,24 & 156,89 & 170,65 & 158,93 \\
\hline & & $\pm 1,55^{\mathrm{e}}$ & $\pm 3,10^{\mathrm{cd}}$ & $\pm 3,21^{\mathrm{e}}$ & $\pm 2,54^{\mathrm{f}}$ & $\pm 8,26$ \\
\hline & \multirow{2}{*}{ A1 } & 147,48 & 138,13 & 156,07 & 143,72 & 146,35 \\
\hline & & $\pm 1,28^{\mathrm{bc}}$ & $\pm 0,05^{\mathrm{a}}$ & $\pm 3,34^{\mathrm{de}}$ & $\pm 6,09^{\mathrm{b}}$ & $\pm 7,53$ \\
\hline & \multirow{2}{*}{ Rataan } & 152,22 & 144,69 & 156,47 & 157,19 & 152,64 \\
\hline & & $\pm 6,70$ & $\pm 9,27$ & $\pm 0,56$ & $\pm 19,04$ & $\pm 8,89$ \\
\hline \multirow{6}{*}{$\begin{array}{c}\text { Pertambahan } \\
\text { Bobot Badan } \\
\text { (gram ekor-1 }^{-1} \\
\text { hari }^{-1)}\end{array}$} & \multirow{2}{*}{ A0 } & 75,59 & 63,93 & 72,83 & 81,58 & 73,48 \\
\hline & & $\pm 1,83$ & $\pm 1,52$ & $\pm 1,05$ & $\pm 3,08$ & $\pm 7,34^{\mathrm{a}}$ \\
\hline & \multirow{2}{*}{ A1 } & 73,37 & 58,16 & 70,06 & 64,90 & 66,62 \\
\hline & & $\pm 3,38$ & $\pm 4,75$ & $\pm 6,74$ & $\pm 9,38$ & $\pm 6,63^{\mathrm{b}}$ \\
\hline & \multirow{2}{*}{ Rataan } & 74,48 & 61,05 & 71,45 & 73,24 & 70,05 \\
\hline & & $\pm 1,57^{\mathrm{b}}$ & $\pm 4,08^{\mathrm{a}}$ & $\pm 1,96^{\mathrm{b}}$ & $\pm 11,79^{\mathrm{b}}$ & $\pm 4,85$ \\
\hline \multirow{6}{*}{ Konversi Pakan } & \multirow{2}{*}{ A0 } & 2,08 & 2,37 & 2,15 & 2,09 & 2,17 \\
\hline & & $\pm 0,03$ & $\pm 0,04$ & $\pm 0,06$ & $\pm 0,07$ & $\pm 0,13$ \\
\hline & \multirow{2}{*}{ A1 } & 2,01 & 2,39 & 2,24 & 2,24 & 2,22 \\
\hline & & $\pm 0,11$ & $\pm 0,20$ & $\pm 0,18$ & $\pm 0,26$ & $\pm 0,15$ \\
\hline & \multirow{2}{*}{ Rataan } & 2,05 & 2,38 & 2,20 & 2,17 & 2,20 \\
\hline & & $\pm 0,05^{\mathrm{b}}$ & $\pm 0,01^{\mathrm{a}}$ & $\pm 0,06^{\text {ba }}$ & $\pm 0,10^{\text {ba }}$ & $\pm 0,03$ \\
\hline
\end{tabular}

Keterangan: A0: Tanpa pembatasan, A1: Pembatasan $20 \%$. B0: Pakan komersial, B1: Kulit kopi, B2: Dedak padi, B3: Ampas kelapa. Superskrip berbeda menunjukkan perbedaan yang nyata $(\mathrm{P}<0,05)$. 
antara $138,13 \pm 0,05-170,65 \pm 2,54$ gram ekor $^{-1}$ hari $^{-1}$. Rataan konsumsi pakan tertinggi diperoleh pada kombinasi perlakuan ampas kelapa tanpa pembatasan dan terendah pada kombinasi perlakuan kulit kopi dengan pembatasan pakan 20\%. Hasil analisis ragam, menunjukkan bahwa terdapat interaksi nyata $(\mathrm{P}<0,05)$ antara pembatasan pakan dan sumber serat terhadap konsumsi pakan. Hasil uji Tukey menunjukkan bahwa, konsumsi pakan ayam pedaging yang mendapat kombinasi perlakuan pakan ampas kelapa tanpa pembatasan (A0B3), nyata lebih tinggi $(\mathrm{P}<0,5)$ dibandingkan dengan semua kombinasi perlakuan pakan. Kombinasi perlakuan A0B0, A0B2 dengan A1B2 memberikan konsumsi pakan yang tidak nyata $(P>0,05$. Demikian halnya dengan konsumsi pakan antara kombinasi perlakuan A1B2 dengan A0B1, antara A0B1 dengan A1B0, dan antara A1B0 dengan A1B3. Kombinasi perlakuan pakan kulit kopi dengan pembatasan pakan $20 \%$ (A1B1) nyata $(\mathrm{P}<0,05)$ lebih rendah dibandingkan dengan semua kombinasi perlakuan lainnya. Tingginya konsumsi pakan pada kombinasi perlakuan ampas kelapa tanpa pembatasan pakan dalam penelitian ini diduga karena ampas kelapa mengandung serat galaktomanan sebesar 61\% (Purawisastra, 2001) yang dapat membantu proses pencernaan. Galaktomanan adalah polisakarida yang terdiri dari rantai mannose dan galaktosa, senyawa ini bermanfaat bagi kesehatan karena mengandung serat dan polisakarida, juga berperan memicu pertumbuhan bakteri usus yang membantu pencernaan (Yamin, 2008).

\section{Pengaruh Perlakuan terhadap Pertambahan Bobot Badan}

Rataan pertambahan bobot badan ayam selama penelitian pada Tabel 3 tersebut, menunjukkan bahwa nilai rataan pertambahan bobot badan bervariasi antara $58,16 \pm 4,75-81,58 \pm 3,08$ gram ekor $^{-1}$ hari $^{-1}$. Rataan pertambahan bobot badan tertinggi diperoleh pada kombinasi perlakuan pakan ampas kelapa tanpa pembatasan pakan (A0B3) dan terendah pada kombinasi perlakuan pakan kulit kopi dengan pembatasan pakan 20\% (A1B1). Hasil analisis ragam menunjukkan bahwa tidak terdapat interaksi antara kombinasi perlakuan pembatasan pakan dan sumber serat $(\mathrm{P}>0,05)$, akan tetapi pada masingmasing perlakuan pembatasan pakan dan sumber serat menunjukkan pengaruh nyata $(\mathrm{P}<0,05)$ terhadap pertambahan bobot badan ayam pedaging strain Lohman. Hasil uji Tukey untuk perlakuan pembatasan pakan menunjukkan bahwa pertambahan bobot badan ayam pedaging yang mendapatkan pakan tanpa pembatasan nyata lebih tinggi $(\mathrm{P}<0,05)$ dibandingkan 
dengan ayam pedaging yang mendapatkan pakan yang dibatasi 20\%. Perbedaan pertambahan bobot badan ini diduga dipengaruhi oleh jumlah pakan yang diberikan dan total konsumsi harian ayam pedaging. Kiha et al. (2012). menyatakan bahwa faktor-faktor yang mempengaruhi pertambahan bobot badan ayam pedaging adalah jumlah konsumsi pakan dan kandungan nutrisi yang terdapat dalam pakan. Hasil uji Tukey pada perlakuan sumber serat, menunjukkan bahwa pertambahan bobot badan ayam pedaging strain Lohman yang mengkonsumsi pakan komersial, dedak padi dan ampas kelapa memperlihatkan perbedaan yang tidak nyata $(\mathrm{P}>0,05)$. Pakan dengan sumber serat kulit kopi berpengaruh nyata $(\mathrm{P}<0,05)$ lebih rendah dibandingkan kombinasi perlakuan lainnya dilihat dari pertambahan bobot badan ayam penelitian. Hal ini diduga karena pertambahan bobot badan berhubungan dengan konsumsi pakan. Semakin tinggi konsumsi pakan maka bobot badannya akan semakin besar, sebaliknya semakin rendah konsumsi pakan maka bobot badannya semakin kecil (Tilman et al., 1991). Hal ini terjadi karena salah satu fungsi pakan bagi unggas adalah untuk pertumbuhan.

\section{Pengaruh Perlakuan terhadap Konversi Pakan}

Konversi pakan merupakan salah satu tolak ukur untuk menilai tingkat efisiensi penggunaan pakan. Jika nilai konversi pakan yang ditunjukkan tinggi, maka efisiensi penggunaan pakan rendah. Sebaliknya jika nilai konversi pakan rendah, maka efisiensi penggunaan pakan tinggi atau baik. Faktor yang mempengaruhi konversi pakan adalah konsumsi pakan dan pertambahan bobot badan. Rataan konversi pakan selama penelitian pada Tabel 3 tersebut menunjukkan bahwa nilai rataan konversi pakan bervariasi antara 2,01 $\pm 0,11-2,39$ $\pm 0,20$. Rataan tertinggi diperoleh pada kombinasi perlakuan pakan kulit kopi dengan pembatasan pakan 20\% (A1B1) dan terendah pada kombinasi perlakuan pakan komersial dengan pembatasan pakan $20 \%$ (A1B0). Hasil analisis ragam menunjukkan bahwa tidak terdapat interaksi antara kombinasi perlakuan pembatasan pakan dan sumber serat $(\mathrm{P}>0,05)$, akan tetapi pada perlakuan sumber serat menunjukkan pengaruh yang nyata $(\mathrm{P}<0,05)$ terhadap konversi pakan ayam pedaging strain Lohman. Hasil uji Tukey menunjukkan bahwa, di antara perlakuan pakan mengandung kulit kopi, dedak padi dan ampas kelapa memberikan konversi pakan yang sama $(P>0,05)$, demikian pula dengan perlakuan pakan komersial, dedak padi dan ampas kelapa. Akan tetapi pakan komersial nyata $(\mathrm{P}<0.05)$ lebih rendah konversi 
pakannya dibandingkan dengan pakan mengandung kulit kopi. Angka konversi pakan yang dihasilkan erat kaitannya dengan jumlah konsumsi pakan dan pertambahan bobot badan (Akmal dan Filawati. 2008). Angka konversi yang semakin tinggi pada perlakuan sumber serat pakan kulit kopi, diduga karena kandungan zat anti nutrisi dalam kulit kopi yakni tanin dan kafein berperan dalam menghambat pemanfaatan pakan yang dikonsumsi secara maksimal (Murib et al., 2016).

\section{KESIMPULAN}

Pembatasan pakan sebesar 20 persen selama 8 hari dengan sumber serat kasar ampas kelapa dalam pakan memberikan hasil terbaik dibandingkan dengan kulit kopi dan dedak padi terhadap performa ayam pedaging strain Lohman periode finisher.

\section{UCAPAN TERIMA KASIH}

Ucapan terima kasih disampaikan kepada Pemerintah Republik Indonesia Kementrian Riset Teknologi dan Pendidikan Tinggi, sebagai penyandang dana penelitian dengan nomor kontrak 087/SP2H/LT/DRTM/2018.

\section{DAFTAR PUSTAKA}

Akmal dan Filawati. 2008. Pemanfaatan kapang Aspergillus niger sebagai inokulan fermentasi kulit kopi dengan media cair dan pengaruhnya terhadap performans ayam broiler. Jurnal Ilmu-Ilmu Peternakan 11(3):150-158

Kiha, A. F., W. Murningsih dan Tristiarti. 2012. Pengaruh pemeraman ransum dengan sari daun pepaya terhadap kecernaan lemak dan energi metabolis ayam broiler. Animal Agricultural Journal 1(1):265-276.

Londok, J. J. M. R., B. Tulung, Y. H. S. Kowel dan J. E. G. Rompis. 2012. Effect of feed restriction on feed efficiency, carcass quality and digestive organs charactheristic of broiler. Proceeding the $2^{\text {nd }}$ International Seminar "Feed Safety for Healty food". AINI and Faculty of Animal Husbandry. Universitas Padjajaran. Jatinangor.

Londok, J. J. M. R. 2018. Produksi Daging Ayam Fungsional Tinggi Asam Laurat dan Antioksidan Alami Melalui Penggunaan Minyak dan Areca vestiaria Giseke. Disertasi. Program Pasca Sarjana IPB. Bogor.

Londok, J. J. M. R., R. A. V. Tuturoong dan J. E. G. Rompis. 2018. Pengaruh Pembatasan Pakan (feed restriction) terhadap Performa Dua Strain Ayam Broiler Periode Starter. Laporan Akhir Riset Terapan Unggulan Unsrat. Universitas Sam Ratulangi, Manado.

Murib, S., M. Najoan, B. Bagau dan I. M. Untu. 2016. Pengaruh substitusi dedak halus dengan tepung kulit kopi dalam pakan terhadap performa broiler. Jurnal Zootek 36(1):218-225.

Purawisastra, S. 2001. Penelitian pengaruh isolat galaktomanan kelapa terhadap 
penurunan kadar kolesterol serum kelinci. Center for Research and Develovment of Nutrition and Food NIHRD. Badan Litbang Kesehatan. Jakarta.

Tilman A. D., H. Hartadi, S. Reksohadiproyo, S. Prawirokusumo dan S. Lebdosoekojo. 1991. Ilmu Makanan Ternak Dasar. Gajah Mada University Press. Yogyakarta.

Tulung, B., J. J. M. R. Londok dan M. N. Regar. 2015. The effect of length of feeding and level of crude fiber carccas quality and serum cholesterol of broiler chicken. Proceeding the 4nd Internasional Seminar of AINI. September 8-9, 2015, AINI and Faculty of Animal Husbandry Sam Ratulangi University. Manado.

Yamin, M. 2008. Pemanfaatan ampas kelapa dan ampas kelapa fermentasi dalam ransum terhadap efisiensi ransum dan Income Over Feed Cost Ayam Pedaging. Jurnal Agroland 15(2):135-139. 